\title{
Interrogating Structural Conflicts and Constitutionalism in Nigeria
}

\author{
Aborisade Olasunkanmi \\ Ladoke Akintola University of Technology Ogbomoso, Ogbomoso, Nigeria \\ Email: aborisaderose@yahoo.com,Omoboy41@gmail.com
}

How to cite this paper: Olasunkanmi, A. (2019) Interrogating Structural Conflicts and Constitutionalism in Nigeria. Open Access Library Journal, 6: e5488. https://doi.org/10.4236/oalib.1105488

Received: May 22, 2019

Accepted: June 25, 2019

Published: June 28, 2019

Copyright $\odot 2019$ by author(s) and Open Access Library Inc.

This work is licensed under the Creative Commons Attribution International License (CC BY 4.0).

http://creativecommons.org/licenses/by/4.0/

\begin{abstract}
This work focuses on structural conflicts and constitutionalism in Nigeria. The research shows that structural conflict is endemic in Nigeria. The work gives many examples of this action as they occur. Constitutionalism on the other hands, is a commitment to the laid down rules. Constitutionalism seeks to provide for a politico-economic order that is inclusive, equitable and responsive to the divergent interests in the society through the instrumentation and institution of limited government. With this, the paper identifies structural conflicts as a major peace and security challenges confronting Nigeria and identifies the potentialities of constitutionalism as a Preventive, ameliorative, and curative mechanism for new and emerging threats to peace and security in Nigeria. The paper concludes that to achieve a compliance with the dictate of constitutionalism that can put an end to structural conflicts in Nigeria, the government will have to make it a deliberate action, such as evolving a mechanism where technocrats would be empowered to ensure compliance with ethos of constitutionalism that will guarantee a country free of structural conflicts.
\end{abstract}

\section{Subject Areas}

Politics

\section{Keywords}

Constitutionalism, Commitment, Government, Structural Conflict, Nigeria

\section{Introduction}

Conflict can be considered as a social necessity and a normal, functional and indeed inevitable aspect of the healthy functioning of all societies [1]. According to Dougherty and Flatfgraff [2], conflict is defined as a condition in which one 
identifiable group of human beings (whether tribal, ethnic, socio-economic, political, amongst others) is engaged in conscious identifiable human groups because these groups are pursuing goals. Similarly, Brandon M. [3] posits that conflict entails an expression of the heterogeneity of interests, values and beliefs that arise as new formations generated by social change come up against inherent constraints. Conflict is therefore an intrinsic and inevitable aspect of social change that can also be seen as the pursuit of incompatible interest and goals by different groups [4].

Structural conflict is a theory that attempts to explain conflict as products of the tension that arises when groups must compete for scarce recourses. The structural conflict theory has two sub-variants. The first strand is the radical approach as propounded by the Marxist dialectical school with exponents like Karl Marx and Frederick Engels, V.I. Levim etc. The second doxy is the liberal structuralism represented by scholars like Johan Galting [5] on structural violence. It is also sometimes similar to transformative theory which addresses the reactions of individuals, groups, cultures, institutions and societies to change. It further sees incompatible interest based on competition for resources which in most cases are assumed to be scarce as being responsible for social conflicts. The main argument of the structural conflict theory is that conflict is built into the particular ways societies are structured and organized.

The theory looks at social problems like political and economic exclusion, injustice, poverty, disease, exploitation, inequality etc. as sources of conflict. Whenever there is conflict, a useful way to begin analyzing what is happening is to find out the resources that are disputed, and how those resources are allocated between the parties involved under different conditions. For instance, during the Apartheid system in South Africa, all the above features manifested until majority rule was enthronement in 1994. The emphasis of this theory is based on how the competing interest of groups ties conflict directly into social, economic and political organizations. Thus, when the social, political and cultural processes are monopolized by a group (Class), it creates the condition that makes people adopt an adversarial approach to conflict. The idea is that conflict arises over how resources are allocated, and if we change the allocation or structure of resources, back it up with constitutionalism, then we can change the conflict, hopefully into cooperation.

\section{Structural Conflicts in Nigeria}

Structural conflict is a serious social unrest that forces the existing system to radically change or modify to accommodate the alienated and dissatisfied ones. With particular reference to Nigeria, Okafo [6] argues that the structural crisis is experienced in the persistent social conflicts that have continued to threaten national harmony in relation to the challenges of unfair distribution of resources and some of the factors such as poverty, corruption ethno-religious upheavals, political instability, boundary disputes, and bad leadership, to mention but a few 
that encourages and exacerbates conflicts in the country According to JohanGaltung [5], the kernel of the concept is that conflicts are structured into the society like “... political and economic exclusion, injustice, poverty, disease, exploitation, inequity etc., as sources of conflict" [7]. They are entrenched in the structure of the society and can lead to adverse consequences because they are politically and economically repressive in form of exclusionary and discriminatory policies against certain groups. Obiora C. Okafor, [6] for seen that; Nigeria is faced with extremely serious structural crisis as evident in the intensity of the conflicts and conflagrations that have attended the country's post-independence social interactions. These are manifested in the form of perceived lack of true federalism and regional autonomy; resource control; the national revenue allocation formula; the establishment of the state police forces; the institution of shariah criminal law in certain northern Nigerian states; and the calls for a national conference as evidence of the existence structural conflicts in the country.

A renowned sociologist Onigu Otite, sees Nigeria society as a social system compounded by contested demands on access to scarce resources especially in the political and economic fields. It is a society defined by national cleavages and manmade conflicts. National membership of ethnic groups and occupational specialisations threatened by the expanding interest of the other multiple users in the same or adjourning ecological zones provide grounds for the emergence of conflicts [8]. There always a rise in "intensity or scale of violence, demographic explosion, social fragmentation and decay, sectarian upheaval, communalisation of political practice, catastrophic balance between ethnic groups, economic and political fissures and suppressions and articulation of primordial and class interests." [9]. These are structural issues led to the fratricidal Nigerian civil war and other violent conflicts such as the Ife/Modakeke conflict, Jos-Plateau conflicts, Kaduna conflicts, Kafanchan conflict, ZangonKataf conflict, Ugep conflict, Tiv/Jukun/Kuteb/Fulani conflicts, Shagamu conflict, Aguleri/Umuleri conflict, Ezza/Ezzilo conflict etc. The structural conflicts also manifested in agitations by the Movement for the Actualization of the Sovereign State of Biafra (MASSOB); the Maitatsine uprising and the various violent extremisms in Northern Nigeria including the Boko Haram insurgency, and the Niger Delta crises; which Oil resources fueled violence, this has raged in many form for over five decades. It could be argued that structural violence started with the discovery in 1958 of oil resources in commercial quantity at Olobiri community, the present day Bayelsa state. This discovery and many more stimulated what John Gaitung [5] defines as 'avoidable impairment of fundamental human needs or to put it in more general terms, the impairment of human life which lower the actual degree to which someone is able to meet the needs below that which would otherwise be possible. This was because oil activities started with no regard to the challenge the swampy terrain and fragile ecology, once disturbed, would pose to countries, second, no consideration was given to eventual loss. Significantly, these crises have shown a unique pattern that challenged fundamental structural issues concerning fiscal, governance, security 
and constitutional arrangements of the country. It is however obvious that the fears are not necessarily associated with public policies or institutional frameworks but with the execution of the public policies and the administration of institutional frameworks. It is in this light that the next subheading examines the potentialities of constitutionalism as a veritable instrument for managing structural conflicts in Nigeria.

\section{Constitutionalism and the Management of Structural Conflicts in Nigeria}

However, before going into constitutionalism, it is pposite to know something about the concept of constitution, since the whole idea of constitutionalism conceptually emerges from that of the constitution, it is also important to briefly examine how the idea of constitutional development comes up. What is constitution? According to Appadorai [10], a constitution, in general terms, is the body of rules which directly or indirectly affect the distributions or the exercise of the sovereign power in the state. The foregoing understanding of the constitution states that it is all about a body of rules that focuses on the exercise of governmental power within a state. If this is all that the constitution has to offer, then one could reasonably state that this conception advances just a partial knowledge of the concept of constitution. The reason is that even a dictatorship has a body of rules that shows how governmental power is dispensed within the state. However, most political philosophers would call this body of rules something other than the constitution. Nevertheless, our present conception of the constitution does not theoretically make a clear-cut distinction between a body of rules guiding the state under civilian regime and the one guiding the state under military dictatorship. Thus, we shall state that the present conception of the constitution is theoretically inadequate.

To this end, we shall share the understanding of the constitution given by JubrilBala Mohammed. According to him;

a constitution, being the fundamental system of the law in any sovereign state, ... provides definition for the citizenship an institution; prescribes rights, responsibilities, obligations and duties, distributes, secures and limits authority and powers, aggregates and articulates aspirations and interests and; outlines procedures for actions, and interactions and; sanctions default [11].

From the above understanding of the constitution, we cannot but note the difference between a body of rules guiding the state in a democratic dispensation and what obtains under a military regime. The specific details in the present conception of the constitution make an improvement upon the first conception in that the details make us understand that the constitution entails more than being an instrument of distribution of power in the state. Thus, while one could rationally state that the first understanding of the constitution could as well apply to dictatorship, the present understanding obviously forecloses such an ap- 
plication. After all, it clearly shows that the constitution is the most fundamental system of law in the state; the ultimate authority is the state. However, under a military dictatorship, the military leaders constitute the ultimate authority in the state, while their decrees form the most fundamental system of regulation.

In the exposition of the concept of constitution, De Smith and Brazir [12] state that constitutions are primarily about political authority and the location of power, conferment, distribution, exercise and limitation of authority and power among the agents of a state. They are concerned with matters of procedure as well as substance. They also include explicit guarantee of the rights and freedom of individual as well as incorporate ideological pronouncements, that is principles by which the state ought to be guided or to which it ought to aspire and statements of the citizens' duties.

This expansive understanding, it must be noted, gives us some features of the constitution that help us delineate it from what it is not. The conception explains that the constitution states and limits the powers of the organs of government as well as regulates the behaviours of the citizens, be it in relation to them or to the state. Thus, one could reasonably contend that the constitution is a logical instrument of state as well as social control and regulation baring a higher status. It is said to have a higher status in the sense that, it is supposed to be higher than any other body of legal regulations in human society.

\section{Constitutional Development}

Having examined what the concept of constitution is all about, the question that comes up is; of what relevance is the emphasis on constitutional development in the society to human beings. A series of systematic answer had been provided, but the one that seems most popular is the social contract theory. According to this theory, constitutional development is an epi-phenomenon of the civil society which itself came into being through the people who were highly displeased with the inconveniences in their pre-society. The theory goes on that, after the people have consented to the formation of a civil society, the rationale step that follows is a pursuit of a system of body of laws within the civil society that adequately protects and regulates the lives of the people so that they do not revert to an unpleasant situation, which obtained in their pre-social life.

In fact, the proponents of social contract theory contend that it is the fear of unpleasantness of the pre-social life that has made the men in the civil society to lay much emphasis on constitutionalism as a veritable instrument of functional social regulation in the society. Constitutionalism is a form of political thought and action that seeks to prevent tyranny and guarantees the liberty and rights of individuals on which free society depends [12]. It is based on the idea that government can and should be limited in its powers, and that its authority depends on enforcing these limitations. Scholars had examined constitutionalism from the liberal and radical angles. The liberals see constitutionalism within the confines of legality or "legalistic interpretation" [13]. One of such is Louis Henkin, 
who describes constitutionalism as the rule of the constitution without derogation from its letters [13]. He then sees constitutionalism as constituting the following elements: government according to the constitution; separation of powers; sovereignty of the people and democratic government; constitutional review; independent judiciary; limited government subject to a bill of individual rights; police control; civilian control of the military; and no state power, or very limited and strictly circumscribed state power, suspension of the operation of some parts of, or, the entire, constitution [13]. Invariably, constitutionalism, according to Henkin, is the legal limitations placed upon the rightful power of government in its relation to the citizens. It also includes the doctrine of official accountability to the people or to its legitimate representatives within the framework of fundamental law for better securing citizen's rights. The philosophy behind the doctrine suggests that the people are the best judge about issues that concern them. Louis Henkin further revealed the rule of law as:

a dynamic concept for the expansion and fulfilment of which jurists are primarily responsible and which should be employed not only to safeguard and advance the civil and political rights of the individual in a free society but also to establish social, economic, cultural and educational conditions under which his legitimate aspirations and dignity may be realized [13].

In other words, Henkin is of the view that the rule of law focuses on the improvement of the material condition of the person in the society. However, this does not capture the obligation of the governed or the ruled that must be part of the law or constitution. IssaShviji's "new democratic perspectives" [13] and Julius Ihonvbere's "process-led approach," [13], which constitute the radical view functionally fill this vacuum as they see constitution as;

a process for developing, presenting, adopting and utilizing political communities and constituencies, but also defines the rights, duties, and obligations of the citizens in any society essentially, the focus of what we mean by constitutionalism is on two issues: first, the process of constitution-making and the extent to which it is popular and democratic; and second, the available openings institutions, and processes of making the constitution a living document by taking it to the people so that they are in a position to not just have access to it, claim ownership and deploy it in the defense of their individual and collective rights and domestic enterprise [14].

This popular approach to constitutionalism finds expression in what Wole Soyinka calls the immaterial. Soyinka states that;

Parallel to the material provisions that form the basis of such a quest for ideal internal relations within the community, is the inclusion of protocols that guarantee, at some level or the other, the entitlement of each and every individual to say, a role, in the direction of the society to which he or she belongs. Over and above the parameters for contributing to a common pool of wealth and sharing out of the resources of the society, that is, the materi- 
al conditions of existence there are also the immaterial, the crucial intangibles; the right of each constituent entity to a voice in the management of society, in the definition of, and establishment of structures of arbitration between individuals and groups, between groups and the total society and, finally the articulation of rights in a way that ensures that the rights of one do not infringe on the rights of another, or on the rights of society [15].

From the above, it is seen that this popular approach to constitution-making seeks to redefine the class content of constitution in favor of the toiling masses of a given society, given that the constitution is an "expression of the actual relation of force in the class struggle" [16]. Thus, a constitution could be seen as a social contract in a socio-historical context in which there is organic unity between the latter and the spirit of the law. This involves participation by the people themselves in the process of constructing the constitution and their active participation in giving it meaning in the process of social production such that their daily evolving aspirations are not alienated by the power that be in a given society.

In this regard, constitutionalism is a political theory concerned with the architectural structure and basic values of the society and the government. It aims to make the world comprehensible and, to some extent, controllable. Historically, it is preoccupied with the problem of power, particularly the power of those who would rule, especially when that rule might be arbitrary" [17]. Constitutionalism, then, could be understood as the expression of a set of abstract moral principles [18]. It suggests certain principles of right and justice which are entitled to prevail on the basis of their own intrinsic excellence, altogether regardless of the attitude of those who wield the physical resources of the community.

\section{Constitutionalism as a Limitation}

So, when scholars talk of constitutionalism, they mean not only that there are rules creating legislative, executive and judicial powers, but also that these rules impose limits on those powers. Often, these limitations are in the form of individual or group rights against government, such as rights to things like free expression, association, equality and due process of law. But, constitutional limits come in a variety of forms. They concern such things as the scope of authority. For example, in a federal system, provincial or state governments may have authority over health care and education. However, the federal government's jurisdiction extends to national defense and transportation; and the mechanisms used in exercising the relevant powers, procedural requirements governing the form and manner of legislation; and civil right. Technically speaking, the areas of legislative authority of provincial or state governments are consigned to the concurrent legislative list while those of the federal government are in the exclusive legislative list.

Another sense of constitutionalism is embedded in the idea that government should be limited in its powers and that its authority depends on its observing 
these limitations. Charles Fombad, for example, reveals that this clearly means something more than the mere attempt to limit governmental arbitrariness, which is the premise of a constitution, and which may fail, as it has done several times in Africa. The concept today according to him can be said to encompass the idea that a government should not only be sufficiently limited in a way that protects its citizens from arbitrary rule but also that such a government should be able to operate efficiently and in a way that it can be effectively compelled to operate within its constitutional limitations. The ultimate purpose of constitutionalism is stated in the declaration at independence: to secure the inalienable rights of all people through a government established by consent of the governed. According to the declaration, a good constitution limits the power of a government in order to secure the rights of every person, the rights that equally belong to all human beings. If a government fails to secure the rights of the individual, then, the government has failed the people, as such; the citizens have the right to withdraw their political obligation to the government. Our analysis, so far has shown two essential elements of constitutionalism: limited government and the rule of law.

Constitutionalism is important in addressing structure conflicts in the sense that beyond the letters of the constitution, it promotes fundamental ethos such as limited government, popular sovereignty, federalism, fundamental rights, fundamental objectives and directive principles of state policy, separation of powers, checks and balance. Conversely, a constitution without constitutionalism (that is the constitutional ethos) breeds socio-cultural fragmentations, corruption, exclusion, inequality, marginalisation, maladministration and violent conflicts. Since structural conflicts emanate from societal fundamentals, mitigating mechanisms should also subsume and task critical social absolutes. The resort to constitutionalism is the most appropriate instrument that can preventing, ameliorating and curing the root causes of structural conflicts.

\section{Contribution to the Work}

To substantiate my proposition, I have a number of features here that show the effectiveness of constitutionalism. Astrict adherence to constitutionalism is a commitment, not a force. Therefore the issue of structural conflicts could be handled effectively through constitutionalism.

Limited government means that officials cannot act arbitrarily when they make and enforce public decisions. Public officials cannot simply do as they please. Rather, they are guided and limited by laws as they carry out the duties of their government offices. The constitution is the supreme law that guides and limits the exercise of power by government officials. Laws made in conformity to the constitution also guide and limit the actions of government officials. This invariably suggests that constitutionalism is the political theory of limited government, and modern democracies share the commitment of constitutionalism to limiting the powers of government to serving the common good as opposed to serving factional or sectarian interests. Modern democracies also share the 
commitment of liberal constitutionalism to limiting government powers on behalf of protecting the rights of the individual.

Furthermore, limited government as the only legitimate political power is constrained power and all authority is limited by the terms according to which it is delegated. Authority operates only by commission; it is the power used on behalf of others who authorize it for specified purposes and under defined conditions. It also exists under an obligation to serve the best interests of those on whose behalf it is exercised. Authority therefore operates as a trust that emanates from a more fundamental source, and its use is conditioned continuously by the purposes for which it was originally established. These purposes and principle of "trusteeship" not only constrain authority but also sustain it.

In a constitutional democratic society, where constitutionalism is strictly upheld, there is popular sovereignty because the government ultimately derives its power from the people that put the system in place. Since the constitution is the product of the society, the people in consenting to a constitutional system, agree to limit not only their government but also themselves. By so doing, the rights of individuals may be protected not only by the limitations on the power of government, but also by guarantees of specific rights beyond the control of government, or by specific grants of powers to governmental institutions to protect rights. For example, they are bound by the provisions of their constitution until they are formally charged.

The protection as well as the advancement of human rights includes social rights or citizenship rights. As the undisputed priority, they come before any other value and all public institutions and bodies are bound to foster them. Equality among all human beings, and in particular the prohibition of all discriminations on the grounds of race, color, sex, social, status, ethnic origin, and all unjust and prejudicial distinctions is part of human rights, as well as the establishment of an independent judiciary.

Furthermore, the principle of people's sovereignty should be recognized as the base for the establishment and the actions of all collective institutions, which include majority rule as the main decision making technique as well as the subtraction from the supremacy of majority rule of those matters whose regulation may eventually infringe upon the protection of human rights in general and of some minority rights, as well as of other matters which in each case specifics social context are regarded as particularly sensitive so that they may be regulated only on the ground of a particularly high level of consensus, or may even not be regulated at all. The essence of consensus is to transcend the conflicting positions in a way that all the parties involved in the dispute "are able to feel that adequate account has been taken of their points of view in any proposed scheme of future action of co-existence" [19]. There should be full autonomy of the civil and political sphere from the religious sphere in the sense that the public authorities are not allowed to grant privileges to any denomination even if largely majoritarian.

In addition, one of the preoccupations of constitutionalism is the avoidance of 
governmental tyranny through the abuse of power by rulers pursuing their own interests at the expense of the life, liberty, and prosperity of the governed. The theory of governmental distribution of power that attempts to provide a solution to this dilemma is the theory of separation of powers which has been fundamental to the thinking of some political philosophers. According to the French political thinker, Jean Bodin, in his work The Republic (1576) cited in Appadorai, the prince ought not to administer justice in person, but should leave such matter to independent judges. Bodin stated further:

To be at once legislator and judge is to mingle together justice and the prerogative of mercy, adherence to the law and arbitrary departure from it. If justice is not well administered, the litigating parties are not free enough, they are crushed by the authority of the sovereign [20].

Here, we could see the prescription of the separation of governmental powers by Bodin so as to guard against tyranny constituted by the concentration of powers in the hands of one ruler. One could also see the normativity of the theory; it prescribes the norms of how the governmental powers are to be distributed in a state if the problem of dictatorship, which is injurious to the life, liberty and property of the individual, is to be addressed.

Another French political philosopher, Boon de Montesquieu, also affirms the essence of the theory of separation of powers. To him, political liberty is fundamental for the people to live a reasonable good life in society. However, Montesquieu cautions that political liberty is not unlimited freedom. He stated;

In governments, that is, in societies directed by laws, liberty can consist on-

ly in the power of doing what we ought to will and in not being constrained

to do what he ought not to will [21].

But how is this political liberty is to be practically achieved? Montesquieu advances the theory of separation of administrative power within the state. $\mathrm{He}$ contends:

When the legislative and the executive powers are united in the same person, or in the same body of magistrates, there can be no liberty, because apprehensions may arise, lest the same monarch or senate should enact tyrannical laws, to execute them in a tyrannical manner. Again, there is no liberty, if the judiciary power is not separated from the legislative and the executive. Were it joined with the legislative, the life and the liberty of subject would be exposed to arbitrary control; for the judge would be then legislator. Were it joined to the executive power, the judge might behave with violence and oppression [21].

From the above, one could readily deduce that the administrative powers in the state are sufficiently separated. All the features that I listed here are usually established and entrenched in a source of law recognized as higher to any ordinary law and subject to amendment according to specific and extraordinary procedures only and the enforcement of this supreme law must necessarily be 
ensured by some effective systems of judicial review. The higher law itself must be the product of an all-inclusive and negotiated process which may grant the opportunity of participation to all members of the community. However, the application of the democratic principle in the constitution-making procedures may be turned in a way to be reconciled with the pursuit of peace among the members of society as a precondition of fundamental human rights.

\section{The Significant of the Research}

Nigeria being the giant of Africa is having an estimated population of over 200 million. 36 states, 774 Local Government and about 320 tribes. The unity of Nigeria is been threatened with constant structural conflicts. This has given birth to different agitation here and there. All the succeeding government have failed to find any meaningful solution to this ugly situation. It is the belief that, if people at the helms of affairs in this country can take a cognizance look at the recommendation in this work and adhere strictly with it, it is my believe that structural conflicts will be a thing of the past in Nigeria.

\section{The Limitation}

Nigeria government is not known for making use or developing research put across by the researchers. The leaders are well known for following only their own agenda. Few of them only listen to the advice of strong party members or their god fathers. Beside this nothing work in Nigeria, no matter how beautiful the objective may be, some individuals see it as a threat to their will, we make sure that such idea doesn't see the light of the day.

\section{Conclusion}

The paper argued that constitutionalism is a preventive, ameliorative, and curative mechanism against new, emerging and existing threats to peace and security in the country. Because the acceptance of constitution with constitutionalism in a country is an indication that such a society is ready and determined to operate within the dictate of constitutionalism since it is already in their system. Constitutionalism serves as a solution to the issue of structural conflicts which brought about how the resources are being allocated, what are the conditions that produce competition, conflict or cooperation, and how can we change them? Though the questions pose enormous challenges to those interested in conflicts resolution, the solution to this problem involves restructuring social, political, and cultural systems. To achieve compliance with the dictate of constitutionalism that can put an end to structural conflicts in Nigeria, the government will have to make it a deliberate action, such as evolving a mechanism where technocrats would be empowered to ensure compliance with ethos of constitutionalism that will guarantee a country free of structural conflicts. 


\section{Conflicts of Interest}

The author declares no conflicts of interest regarding the publication of this paper.

\section{References}

[1] Alli, W.O. (2012) The Impact of Globalization on Conflicts in Africa. In: Best, S.G., Ed., Introduction to Peace and Conflict Studies in West Africa, Sepectrum Books Limited, Ibadan, 23.

[2] Dougherty, J.E. and Platfgraff, R.L. (1971) Contending Theories of International Relations. Harper and Row Publishers, New York.

[3] Brandon, M.E. (2003) Home on the Range: Family and Constitutionalism in American Continental Settlement.

[4] Bakut, T.B. (2012) The Environment, Peace and Conflict in Africa.

[5] Galtung, J. (1990) Cultural Violence. Journal of Peace Research, 27.

[6] Okafor, O.C. (2003) Convention Refugeehood, Early Warning Signs, and the Structural Crisis of Legitimate Statehood in Contemporary Nigeria. Buffalo Human Rights Law Review, 9, 6.

[7] Ademola, F.S. (2006) Theories of Social Conflict. In: Best, S.G., Ed., Introduction to Peace and Conflict Studies in West Africa, Spectrum Books Limited, Ibadan, 41.

[8] Otite, O. (1990) Ethnic Pluralism and Ethnicity in Nigeria. Shanesson, Ibadan, 12.

[9] Bassey, C. and Fwa, L.K. (2010) Nigeria's Mechanisms for Peace and Conflict Resolution: From Biafra to the Niger Delta. In Maduagwu, M.O., et al., Eds., Nigeria's 50 Years of Nation.

[10] Appadorai, A. (1975) The Substance of Politics. Oxford University Press, Oxford, 247.

[11] Jubril, B.M. (2000) Concept, Theory and Evolution of Constitution. Constitutionalism and National Question. Centre for Constitutionalism and Demilitarisation, Lagos, 16.

[12] Smith, D. and Brazier, R. (1998) Constitutional and Administrative Law. Penguin Book, London and New York, 6-7.

[13] Ihonvbere, J.O. (2000) Towards Participatory Principles and Mechanisms on Constitution Making in Africa. Unpublished Paper Governance and Civil Society Unit, Peace and Social Justice Programm. The Ford Foundation, New York.

[14] Soyinka, W. (2000) Constitution and Continuity-A Key note Address. In Path to People's Constitution, CDHR.

[15] Lenin, V.I. (2000) The History and Politics of Constitution-Making in Nigeria (1922-1999). Ashagate, Aidershort.

[16] Brennan, G. and Buchanan, J.M. (1985) The Reason of Rules: Constitutional Political Economy. Cambridge University Press, Cambridge, 48.

[17] William, E.S. (2002) Constitutionalism in an Age of Speed. Constitutional Commentary, 19, 353-390.

[18] Fombad, M.C. (2007) Challenge to Constitutionalism and Constitutional Rights in Africa and the Enabling Role of Political Parties: Lessons and Perspectives from Southern Africa. The American Journal of Comparative Law, 55, 1-45. https://doi.org/10.1093/ajcl/55.1.1 
[19] Ebijuwa, T. (2003) Consensus as a Valid Political Ideal. Africa: Journal of Contemporary Issues, 1, 59.

[20] Appadorai, A. (1975) The Substance of Politics. Oxford University Press, Oxford, 247.

[21] Montesquieu (2006) Basic World Political Theory Ancient-Contemporary. 2nd Edition, Claretian institute of Philosophy, Oweri, 110. 